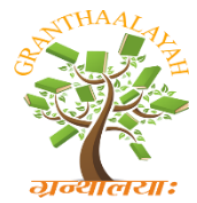

\author{
INTERNATIONAL JOURNAL OF RESEARCH \\ GRANTHAALAYAH \\ A knowledge Repository
}

Social

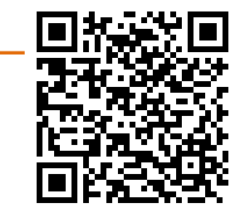

\title{
DISSEMINATION OF INFORMATION WITH REGARD TO RURAL POPULATION ECONOMY THROUGH RURAL LIBRARY: A CASE STUDY OF CHIKKABALLAPUR DISRICT
}

\author{
Ravi Kumar N S ${ }^{1}$, Prasad K N ${ }^{2}$ \\ ${ }^{1}$ Research Scholar and Librarian, Govt. First Grade College, Devanahalli, Bangalore Rural \\ District, India \\ ${ }^{2}$ Executive Officer, Sarada Ranganathan Endowment for Library Science, Bangalore, India
}

\begin{abstract}
Information is raw material used to derive the facts and figures, which can be used by the layman of the nation. The information dissemination is required to build up strong nation and to develop strong economy through the agriculture. The rural public libraries play a pivotal role in nation building by providing information to the rural public and it intern helps in to build up strong economy of the country. The article deals the type of respondents, their educational background, the rural libraries selected for the study, their economic background, their dependence on news channels etc.
\end{abstract}

Keywords: Public Libraries; Dissemination of Information; User Studies; Economy.

Cite This Article: Ravi Kumar N S, and Prasad K N. (2019). "DISSEMINATION OF INFORMATION WITH REGARD TO RURAL POPULATION ECONOMY THROUGH RURAL LIBRARY: A CASE STUDY OF CHIKKABALLAPUR DISRICT.” International Journal of Research - Granthaalayah, 7(1), 34-49. 10.29121/granthaalayah.v7.i1.2019.1030.

\section{Introduction}

An economy consists of the economic system in a certain region, comprising the production, distribution or trade and consumption of goods and services in that region or country. An economy is the total aggregate sum of all transactions of value between two agents such as one individual to another individual or between groups of individual activity such as in one organization to another organization and between one nation to another nation. Transactions only occur when both parties agree to the value, commonly expressed in some currency or price. Then only the sale of good or service acted as the transaction. An economy represents the diverse activity of all agents engaged in the production of valuable goods and services for other agents in the economy.

Rural economies are in large and small sectors, and all over the world it is dealing with the same issues like shortage of natural resources, obtaining the best price for their products, constraints on productivity and adaptation to climatic changes. Though the risks in rural economics are high, too 
often the returns are very low. Unreliable weather, pests, diseases and weeds can ruin the crops and they decrease the income. Farmers must also deal with the risks of a volatile market even with a good crop, prices may be low. As a result, more than three quarters of poor people live in rural areas.

The use of libraries for religious and moral instruction was practiced by all early civilizations. Monastery libraries established during middle pages and libraries attached to modern church have primarily existed to support religious and moral instruction. The same is true about Libraries attached to ashramas, mutts and other religious bodies in India.

Libraries can help in the process of social change to fulfill the aspirations of the people. A Public library can provide access to documents information free of charge for all the community irrespective of any restriction. By providing relevant documents and information, a public library can influence the attitudes of the people in combating prejudicial treatment of certain groups, thus removing barriers between groups of People. A public Library can help in solving social problems of a society in bringing equality of education, in achieving political and social awareness, etc. This is how, it can serve as an agent in the process of social change. The invention of Alphabets played very important part in the establishment of libraries.

\section{Objectives of the Study}

Objectives of the study have been evolved on the basis of research questions raised in the review of literature. Research objectives are given below:

1) To understand the socio, economic and cultural background of rural people.

2) To find out the type of users in the gram panchayat libraries.

3) To assess the educational background of the users of the gram panchayat libraries.

4) To find out the media on which rural people will get the information.

5) To assess the impact of media on the respondents.

6) To find out the other sources of information used by the respondents.

7) To find out the impact of news channels on the rural community.

\section{Limitations of the Study}

Present study would emphasis mainly on impact of dissemination of information to rural population which helps in improving their thinking and understanding level. Sharing of experience and essential feedback from stakeholders will play vital about the kind of information they need and methods of flow of information. Identification and evolution of an effective system to improving their knowledge which will have wider positive impact on their lives is based on the information that will be provided. In spite of defined methodology planned to follow towards collecting data, It is presumed that necessary information may not be provided by people during the discussion and field work. This is considered as limitation of the present study.

\section{Methodology of the Study}

A planned approach has been employed for the data collection so that the facts are near to reality and free from aberration are elicited for impact evaluation. The present study is based on primary 
and secondary source of data. The source of secondary data for the study is existing literature and data in website, various publications of central, state especially rural development departments and other sources like Books, Magazines, News Papers, Reports, Research Articles, and Seminar Papers Published by Universities and Research Institutions. Besides published material, study is based on the discussions with people such as officials of local governments, Village Leaders and Children. Primary survey will be conducted in Chikkaballapur district of Karnataka.

\section{Review of Literature}

The study of review of literature is an important aspect in any research works through which one understands the past trends in research output in any particular discipline. A review is significant step to get clear picture of what has been done and suggested already with regard to problem understanding. The attempt is to highlight the findings of the studies conducted related to this topic which helps to undertake the present study in a systematic manner.

To review the past studies we have consulted the Library and Information Abstracts (LISA) and Library and Information Science Technology Abstracts (LISTA) and others sources likes Books, Journals etc. We studied the sources from 1936 to 2012.

Robert Maynard Hutchins (1936) outlines that library is never passive but dynamic. He reviews the objectives of the library specialized services offered by library and role of library in the research. The aim of the library must be to sell itself go out and promote its services. Library must encourage reading at all levels and for different purposes, reading for education, reading for information, reading for seeking status, reading for emotional release, reading for self-realization, attaining Moksha or spiritual emancipation.

Kaula, P. N (2006) focuses on the needs and development of rural libraries in India. The author mentions the launching of the National Adult Education Program and the follow up program for the establishment of village libraries in several states through various agencies. It also highlights the enforcement of library legislation in some states and the thrust on setting up rural libraries as community resource centers.

Asaba, Jane Frances, Musebe, Richard, Kimani, Martin, Day, Roger, Nkonu, Michael, Mukhebi, Adrian, Wesonga, Albert' Mbula, Regina, Balaba, Peter Nakagwa, \& Alyce (2006) discuses in East Africa agricultural production for local consumption and export plays a critical role in national economies. Agricultural information is a key component in improving small-scale agricultural production and linking increased production to remunerative markets, thus leading to improved rural livelihoods, food security and national economies. Major among them is the ability to engage the communities through building partnerships and capacity for problem solving and establishing 'user knowledge clubs' to promote access to information.

Shivalingappa Anupama \& Tadasad P G (2009) explores the concept of rural librarianship emphasizing the relations between rural developments of the country that is directly proportional to the development of rural based Gram Panchayat Libraries for human empowerment to build information rich society. 


\section{Analysis and Interpretation of Data}

An attempt has been made to interpret and analyze the use and dissemination of information to the rural public to improve their socio-economic background. Questionnaires were distributed among the users of the library and asked to answer all the questions. The data collected were analyzed and inferences made based on standard techniques. Analysis of the data obtained through the questionnaires provided an in depth interpretation for fulfilling the research objectives.

Table 6: Type of the respondents

\begin{tabular}{|l|l|l|l|}
\hline Type of the respondents & Frequency & \% & Cumulative percentage \\
\hline Farmers & 215 & 71.66 & 71.66 \\
\hline Officials & 45 & 15.00 & 86.66 \\
\hline Leaders & 20 & 06.67 & 93.33 \\
\hline Labourers & 20 & 06.67 & 100 \\
\hline Total & $\mathbf{3 0 0}$ & $\mathbf{1 0 0 . 0 0 \%}$ & \\
\hline
\end{tabular}

The above Table No. 6 depicts that $215(71.66 \%)$ respondents are farmers, followed by officials $45(15.00 \%)$ and the least number of respondents are leaders of the gram panchayat and labourers of the villages are $20(6.67 \%)$. The above table clearly shows that farmers are the most frequent users of the gram panchayat libraries for their agricultural information and for entertainment.

Table 7: Taluks and Gram panchayats covered for the study

\begin{tabular}{|l|l|l|l|l|}
\hline Sl. No. & Name of the Taluk & No. Gram Panchayats & \% & CF \\
\hline $\mathbf{1}$ & Chikkaballapur & 19 & 41.30 & 41.30 \\
\hline $\mathbf{2}$ & Shidlagatta & 05 & 10.87 & 52.17 \\
\hline $\mathbf{3}$ & Chintamani & 05 & 10.87 & 63.04 \\
\hline $\mathbf{4}$ & Bagepalli & 05 & 10.87 & 73.91 \\
\hline $\mathbf{5}$ & Gudibande & 05 & 10.87 & 84.78 \\
\hline $\mathbf{6}$ & Gowribidanur & 07 & 15.22 & 100 \\
\hline & Total & $\mathbf{4 6}$ & $\mathbf{1 0 0 . 0 0}$ & \\
\hline
\end{tabular}

Table 7 shows that Taluks and Gram Panchayats covered for the study. For the purpose of the study the gram panchayats have been selected on the basis of simple random sampling and Chikkaballapur taluk which has $19(41.37 \%)$ gram panchayats has been selected for the study. Gowribidanur with 07 (15.22\%) follows. The other taluks viz., Siddlagatta, Chintamani, Bagepalli, Gudibande $05(10.87 \%)$ gram panchayats have also been selected for the study.

The list of gram panchyats selected for the study from the particular taluk on the basis of simple random sampling. The selected gram panchyats library users have been studied thoroughly and collected the primary data, their views and socio-economic background of the users. From Chikkaballapur taluk 19 (41.30\%) libraries have been selected for the study, $6(15.22 \%)$ libraries are selected from Gauribidanur taluk and 5 (10.87\%) libraries selected from Sidlaghatta, Chintamani, Bagepalli and Gudibande each. 
Table 9: Gender wise distribution of the respondents

\begin{tabular}{|l|l|l|l|}
\hline Gender & No. of respondents & $\%$ & CF \\
\hline Male & 182 & 60.66 & 60.66 \\
\hline Female & 118 & 39.34 & 100 \\
\hline Total & $\mathbf{3 0 0}$ & $\mathbf{1 0 0 . 0 0}$ & \\
\hline
\end{tabular}

Table 9 depicts that gender wise distribution of respondents. Males $182(60.66 \%)$ are the highest respondents and females are also competitors with 118 (39.34\%). The females of the rural areas are also using the services of the public libraries and they are competitors for the males in the development of socio-economy of the family. The information is used for the agricultural and for entertainment purposes.

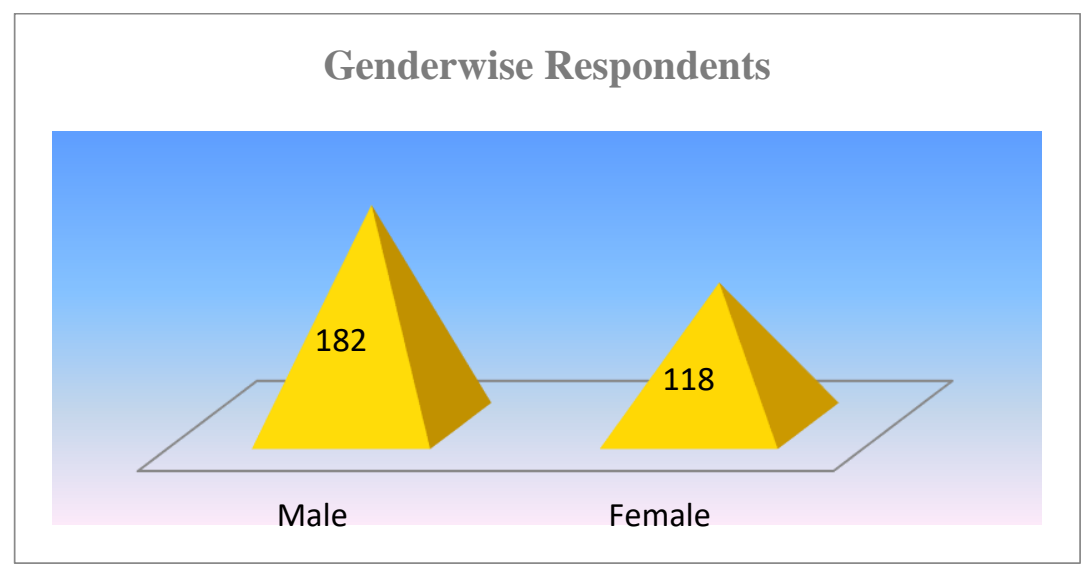

Graph 3: Gender Wise distribution of the respondents

Table 10: Age Group of the Respondents

\begin{tabular}{|l|l|l|l|}
\hline Age Group & No. of Respondents & \% & CF \\
\hline $\mathbf{1 5 - 3 0}$ & 85 & 28.34 & 28.34 \\
\hline $\mathbf{3 0 - 4 5}$ & 105 & 35.00 & 63.34 \\
\hline $\mathbf{4 5 - 6 0}$ & 75 & 25.00 & 88.34 \\
\hline $\mathbf{6 0 - 8 0}$ & 35 & 11.66 & 100 \\
\hline Total & $\mathbf{3 0 0}$ & $\mathbf{1 0 0 \%}$ & \\
\hline
\end{tabular}

Table 10 \& Graph 4 reveals that most of the respondents are in the age group of 30-45 which is $105(35.00 \%)$ followed by $15-30(28.34 \%)$ age group, and it predicts that most of the users of gram panchayat libraries are adults. $35(11.66 \%)$ are senior citizens in the age group 60-80 are using the services of the gram panchayat libraries.

The study concludes that, most of senior citizens $(11.66 \%)$ are using the public libraries for entertainment, for time pass and to give suggestions and guidance to the younger generation.

Table 11: Education of the respondents

\begin{tabular}{|l|l|l|l|}
\hline Education of the respondents & No. of respondents & Percentage & CF \\
\hline Primary School & 90 & 30.00 & 30.00 \\
\hline High School & 105 & 35.00 & 65.00 \\
\hline
\end{tabular}


DOI: 10.5281/zenodo.2550085

\begin{tabular}{|l|l|l|l|}
\hline Degree & 40 & 13.34 & 78.34 \\
\hline No Education & 65 & 21.66 & 100 \\
\hline Total & $\mathbf{3 0 0}$ & $\mathbf{1 0 0 . 0 0}$ & \\
\hline
\end{tabular}

Education is a very important criteria for the development of a nation and economic background of the people. Education plays a vital role in the development of rural people to become stronger in social, cultural and economical aspects of nation. The Table 11 depicts that most of the rural people are studied up to High school $105(35.00 \%)$ level and it is a good sign in the development of the rural society followed by people with Primary School education i.e. $90(30.00 \%)$ have at least education enough to read and write. It also shows that there is no education for 65 (21.66\%) respondents. Which is a hurdle for the development of the nation. The Government of India has always been trying to bring up 100\% literacy programme with Sarva Skishana Abhiyana. Inspite of its people are not going to schools. It is noticed that 40 (13.34\%) respondents are Degree holders, which is a good sign for development.

The hypotheses is tested with one sample Chi-Sqaure test with equal probabilities, the hypotheses rejected the null hypothesis, the significance level being .000 . The Chi-Sqaure test has been administrated and the chi-sqaure value is $32.667^{\mathrm{a}}$ and degree of freedom is 3 . Where a is 0 cells $(0.0 \%)$ have expected frequencies less than 5 . The minimum expected cell frequency is 75.0 .

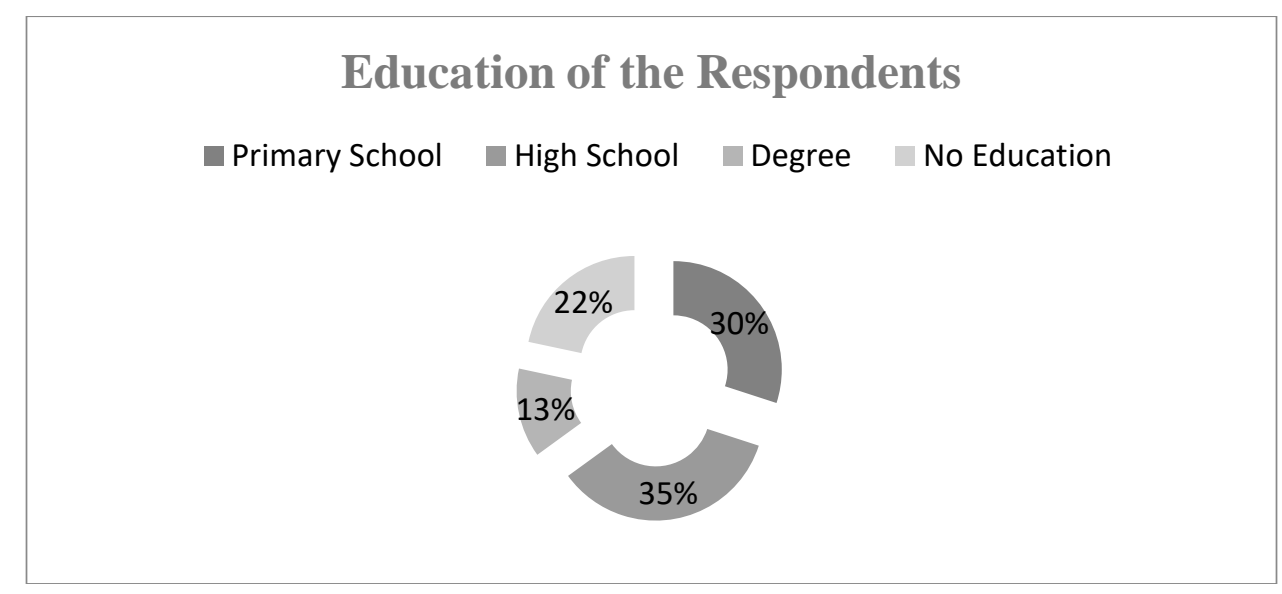

Graph 5: Education of the Respondents

Table 12: Annual Income of the Respondents

\begin{tabular}{|l|l|l|l|}
\hline Annual Income (in Rs) & No. of Respondents & Percentage & CF \\
\hline $\mathbf{2 5 , 0 0 0 . 0 0}$ & 60 & 20.00 & 20.00 \\
\hline $\mathbf{5 0 , 0 0 0 . 0 0}$ & 40 & 13.34 & 33.34 \\
\hline $\mathbf{7 0 , 0 0 0 . 0 0}$ & 80 & 26.66 & 60.00 \\
\hline $\mathbf{1 , 0 0 , 0 0 0 . 0 0}$ & 120 & 40.00 & 100 \\
\hline Total & $\mathbf{3 0 0}$ & $\mathbf{1 0 0 . 0 0}$ & \\
\hline
\end{tabular}

The development of any nation depends on the economic background of the rural people. The economy plays a very important role in providing basic needs of the rural community. Table 12 depicts that $120(40 \%)$ respondents have up to Rs. 1,00,000.00 annual income, this shows that they have better income in the modern world but due to the GDP it may not fulfill the needs of the rural 
community. There is also a large number of people i.e. 60 (20\%) having around Rs. 25,000.00 as annual income. This shows that, a significant number of the rural community are facing the problems of lower economic conditions.

The study reveals that $50 \%$ of the rural community is facing the financial crunches to lead their dignified life in the present society. The rural community is striving to uplift their economy and they are facing many hurdles in achieving the better economy.

The Chi-Sqaure test has been administrated and the chi-sqaure value is $46.667^{\mathrm{a}}$ and degree of freedom is 3 . Whereas a is 0 cells $(0.0 \%)$ have expected frequencies less than 5 . The minimum expected cell frequency is 75.0 .

The basic need of any human being is accommodation to protect himself/herself from natural calamities. The Government of India has taken the initiative to provide a house to each and every person of the country. Graph 7 shows that 248 (82.66\%) of the respondents have own house and $52(17.34 \%)$ are homeless. Hence, more initiatives have to be taken to provide house to homeless people.

The study reveals that, central government and state government are initiated many schemes for constructing houses to the below poverty line people but even then $3 / 4(17.34 \%)$ of the rural community are homeless.

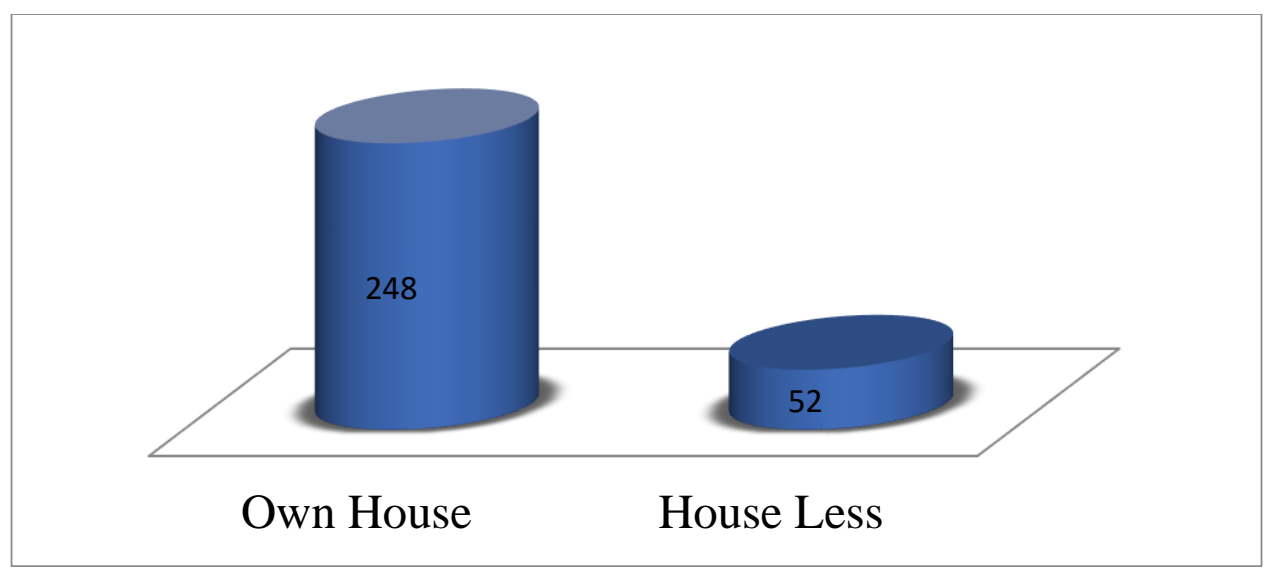

Graph 7: Accommodation of the respondents

Table 14: Land holding of the respondents

\begin{tabular}{|l|l|l|l|}
\hline Land Holding & No. of Respondents & Percentage & CF \\
\hline Land Holder & 256 & 85.33 & 85.33 \\
\hline Landless & 44 & 14.67 & 100 \\
\hline Total & $\mathbf{3 0 0}$ & $\mathbf{1 0 0 . 0 0}$ & \\
\hline
\end{tabular}

Agriculture is the main source of income of the rural community and most of the rural people depend upon agriculture and most of them are agricultural laborers. Land is the main source of economy and they are producing food grains, vegetables, fruits, and flowers. Table 14 shows that $256(85.33 \%)$ of the respondents are having some land and $44(14.67 \%)$ of the respondents are not having any kind of land. 
Table 15: Cultivation of Land by the respondents

\begin{tabular}{|l|l|l|l|}
\hline Cultivation Land & No. of Respondents & Percentage & CF \\
\hline Cultivable Land & 180 & 60.00 & 60.00 \\
\hline Non-cultivable Land & 120 & 40.00 & 100 \\
\hline Total & $\mathbf{3 0 0}$ & $\mathbf{1 0 0 . 0 0}$ & \\
\hline
\end{tabular}

The major source of economy of Chikkaballapur district is agriculture, the agricultural products of this district being exported all over the world. The major crops of the district are ragi, paddy, maize, groundnut, sunflower, etc., vegetables like tomato, cauliflower, onions, beetroot, carrot, etc., and fruits like grapes, mangos etc., flowers like roses, lili flower, marigold etc. Table 15 shows that $180(60 \%)$ of the respondents are having cultivable land to grow food grains, vegetables, fruits and others and $120(40 \%)$ of the respondents are having non cultivable land, but they are using them for other purposes.

Table 16: Agricultural Land of the respondents

\begin{tabular}{|l|l|l|l|}
\hline Agricultural Land & No. of Respondents & Percentage & CF \\
\hline 0 Acres & 44 & 14.67 & 14.67 \\
\hline 2 Acres & 65 & 21.67 & 36.34 \\
\hline 2-5 Acres & 80 & 26.66 & 63.00 \\
\hline 5-10 Acres & 111 & 37.00 & 100 \\
\hline Total & $\mathbf{3 0 0}$ & $\mathbf{1 0 0 . 0 0}$ & \\
\hline
\end{tabular}

Agriculture is the main source of economy of Chikkaballapur district. Most of the rural community have agricultural land with different sizes. $111(37 \%)$ of the respondents are having 5-10 acres of land for cultivation purposes followed by 80 (26.66\%) 2-5 acres of land. There are 44 (14.67\%) respondents not having any kind of land for agricultural purposes, they may be agricultural laborers.

Table 17: Income from the Occupation (Including Expenditure)

\begin{tabular}{|l|l|l|l|}
\hline Income from Occupation & No. of Respondents & Percentage & CF \\
\hline $5,00,000.00$ & 100 & 33.33 & 33.33 \\
\hline $4,00,000.00$ & 80 & 26.66 & 59.99 \\
\hline $2,00,000.00$ & 40 & 13.34 & 73.33 \\
\hline $1,00,000.00$ & 30 & 10.00 & 83.33 \\
\hline $50,000.00$ & 50 & 16.67 & 100 \\
\hline Total & $\mathbf{3 0 0}$ & $\mathbf{1 0 0 . 0 0}$ & \\
\hline
\end{tabular}

The development of the nation or a person depends on the income which plays an important role in development of the basic needs of human being. The income shows the status of an individual. Table 17 shows that $100(33.33 \%)$ of the respondents are having more than Rs. 5 lakhs of income and this shows that the rural community are in good status but in the modern world where there is enormous increase in the GDP of a nation and this income will not be sufficient to lead dignified life. $80(26.66 \%)$ respondents are having up to Rs. 4 lakhs of income and 50 (16.67\%) respondents are having upto Rs. 50 thousand annual income. 
The study infers that, more than $30 \%$ of the rural community is facing financial crunches to lead their life and other $20 \%$ of the rural community is managing their life.

\section{Information Media}

Table 18: Information on Media

\begin{tabular}{|l|l|l|l|}
\hline Media & No. of Respondents & Percentage & CF \\
\hline Television & 120 & 40.00 & 40.00 \\
\hline Radio & 23 & 07.66 & 47.66 \\
\hline Newspaper & 90 & 30.00 & 77.66 \\
\hline Mobile & 23 & 07.66 & 85.32 \\
\hline Library & 44 & 14.68 & 100 \\
\hline Total & $\mathbf{3 0 0}$ & $\mathbf{1 0 0 . 0 0}$ & \\
\hline
\end{tabular}

Rural community is in need of information on the areas like education, political issues, social issues and productive sectors like agriculture and non-agriculture. The community is depends on media's like television, news papers and on libraries to get the information. Libraries play a very important role in disseminating information to the rural community. Table 18 shows that 120 (40\%) respondents opined that television is a fundamental media for disseminating information to the rural community and $90(30 \%)$ respondents opined that newspaper is an another media which play an important role in disseminating information like current affairs, present political situation of the country, current economics, current atmospheric information and other social issues of the country. Another important media the grampanchyat libraries $34(11.34 \%)$ play a very important role in disseminating all kinds of information at one place, but it is to be noted that the usage of these libraries may be less but it is increasing every year and it is good a sign in the development of the community.

Hypotheses: Television is the main source of information to the rural community

The non-parametric test says null hypotheses are rejected and hypotheses have been accepted. The asymptotic significances are displayed and the significance level is .05. The chi-square test is $124.900^{\mathrm{a}}$ and the degree of freedom is 4 . Here a is 0 cells $(0.0 \%)$ have expected frequencies less than 5. The minimum expected cell frequency is 60.0. The standard deviation is 1.446 .

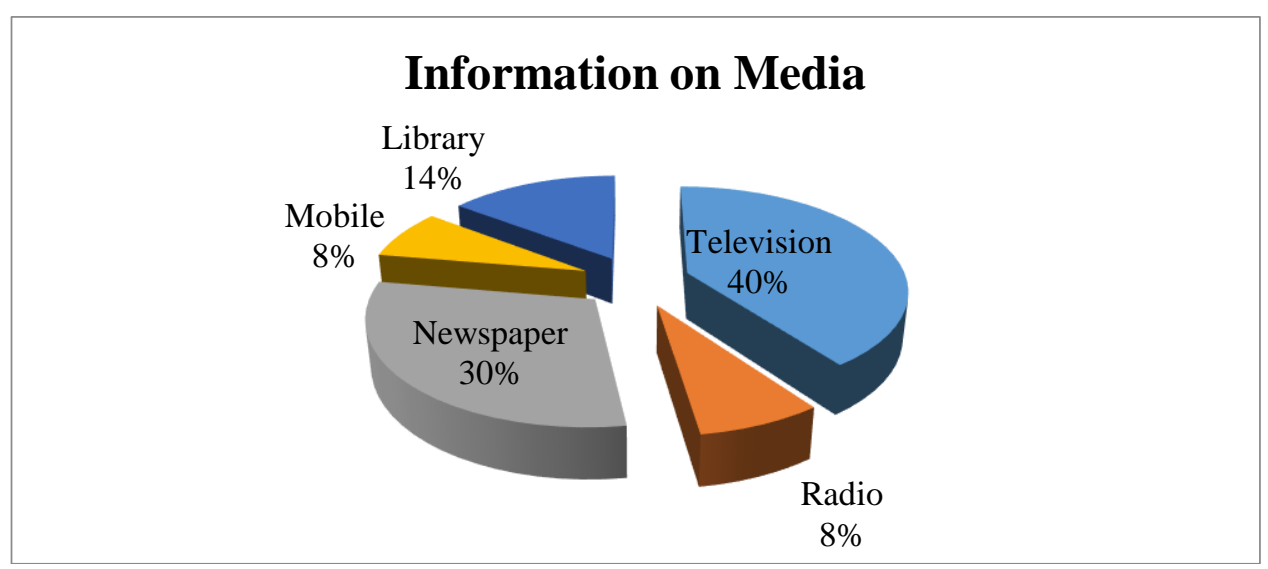

Graph 12: Information on Media 
We asked the question like; do you need any information relating to the above mentioned sectors? Rural community is not depending much on the libraries but media like television and newspapers are providing information on what they want. The libraries are providing all the information at one place and it gives relevant statistics also. Graph 13 shows that among the rural people 240 (80\%) respondents said that they need information on areas like agriculture and non-agriculture and 60 (20\%) respondents said that they are not in need of this information because they have expertise in the traditional agricultural farming.

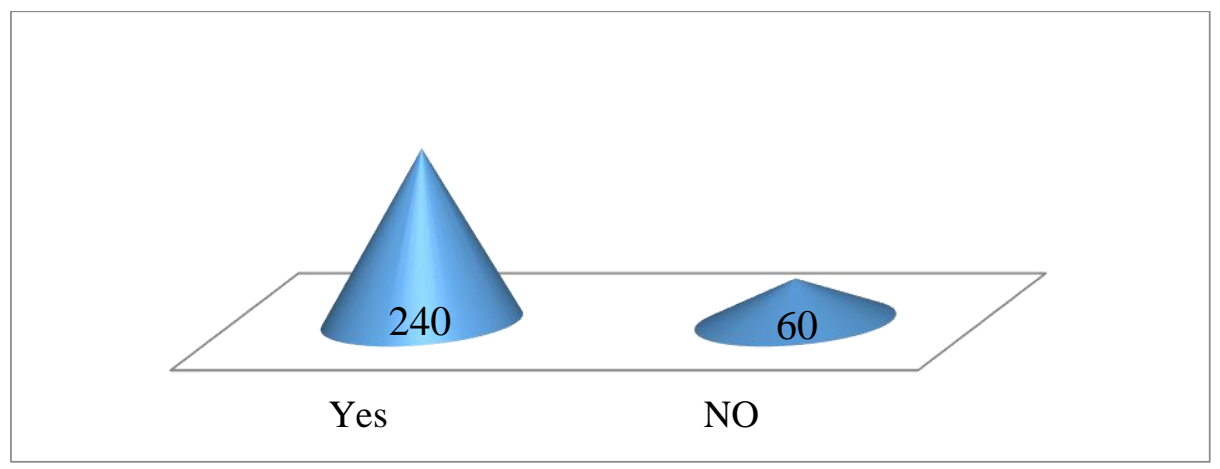

Graph 13: Requirement of Information on Agriculture and Non-Agriculture Topics

\section{Impact of Media on Human Life}

Media is one of the effective sources for dissemination of information all over the world. Television is one of the major sources of information on agricultural and non-agricultural topics for the rural community. Each and every home has got the television with DTH connection and this becomes the part of their life. Mobile phone is also an important source of many kinds of information. Each and every person of the rural community is having the mobile phone and this has both advantages and disadvantages for the progress of the society.

Table 19: Impact of Media

\begin{tabular}{|l|l|l|l|}
\hline & No. of Respondents & Percentage & CF \\
\hline Yes & 240 & 80.00 & 80.00 \\
\hline No & 60 & 20.00 & 100 \\
\hline Total & $\mathbf{3 0 0}$ & $\mathbf{1 0 0 . 0 0}$ & \\
\hline
\end{tabular}

The table 19 reveals that, $240(80 \%)$ respondents said that media is having positive impact on human beings and this shows that the rural community depends on the media for information, and $60(20 \%)$ of the respondents said that media has no impact they depend on the other media like self experience and they also get information for other friends.

Table 20: Usefulness of media

\begin{tabular}{|l|l|l|l|}
\hline & No. of Respondents & Percentage & CF \\
\hline Yes & 210 & 70.00 & 70.00 \\
\hline No & 90 & 30.00 & 100 \\
\hline Total & $\mathbf{3 0 0}$ & $\mathbf{1 0 0 . 0 0}$ & \\
\hline
\end{tabular}

We have asked the question like "Do you think the information acquired from the media other than from the library is very useful?" Table 20 shows that $210(70 \%)$ respondents states that media is 
more useful than library and $90(30 \%)$ respondents said that media is not that much important. This shows that media is quite popular among rural community and Grampanchyat libraries are not very popular. The media is very popular because maximum number of houses has got the television and mobile phones. The libraries are not popular because of the timings, services, sources and co-operation of the library staff etc.

The chi-square test result is $48.000^{\mathrm{a}}$ and the degree of freedom is 1 and the standard deviation of the variable is 0.459 .

\section{Other Sources of Information}

The information is available in various forms and formats. The sources may be varying from one to many and the authenticity of the information also may vary. The sources of information may be available in formal and informal ways. The information could be raw material presented in the form of facts and figures.

Table 21: Other Sources of Information

\begin{tabular}{|l|l|l|l|}
\hline Sources of Information & No. of Respondents & Percentage & CF \\
\hline Agricultural Office & 80 & 26.67 & 26.67 \\
\hline Grampanchyat Office & 90 & 30.00 & 56.67 \\
\hline Friends & 41 & 13.66 & 70.33 \\
\hline Farmers & 62 & 20.67 & 91 \\
\hline Educators & 27 & 09.00 & 100 \\
\hline Total & $\mathbf{3 0 0}$ & $\mathbf{1 0 0 . 0 0}$ & \\
\hline
\end{tabular}

Table 21 shows that $90(30 \%)$ respondents are getting their required information from grampanchyat offices, followed by 80 (26.67\%) respondents getting their information from agricultural offices. $62(20.67 \%)$ respondents are getting their information from the other farmers of the village.

The chi-square test result is $45.900^{\mathrm{a}}$ and the degree of freedom is 4 and the standard deviation of the variable is 1.578 .

The table 21 infers that, $1 / 2$ of the respondents are getting their required information from their friends, farmers and from literates of their villages.

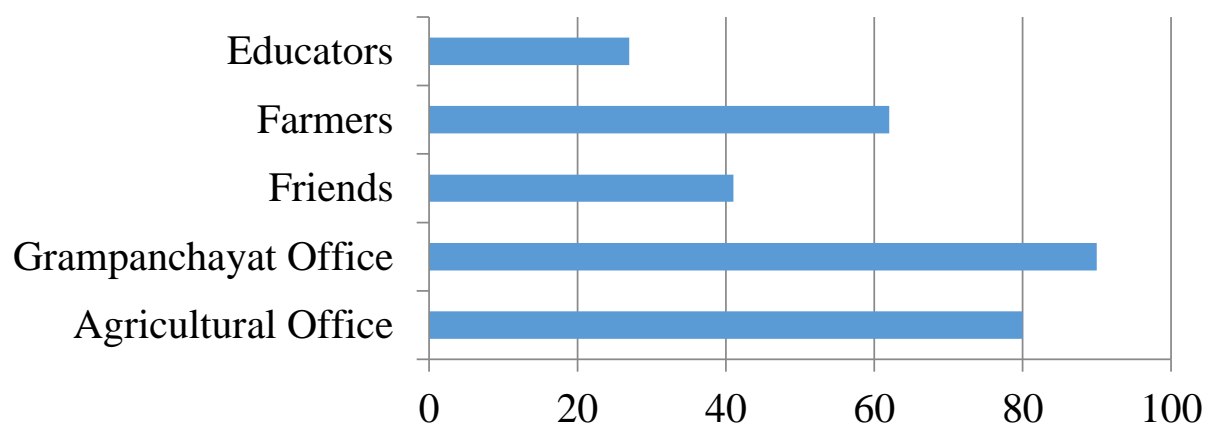

Graph 16: Other sources of Information 
Table 22: Television at Home

\begin{tabular}{|l|l|l|l|}
\hline & No. of Respondents & Percentage & CF \\
\hline Yes & 233 & 77.66 & 77.66 \\
\hline No & 67 & 22.34 & 100 \\
\hline Total & $\mathbf{3 0 0}$ & $\mathbf{1 0 0 . 0 0}$ & \\
\hline
\end{tabular}

Table 22 shows that $233(77.66 \%)$ respondents are having the television in their homes. This is most widely accepted and familiar medium for disseminating information. They may be using it for different purposes. 67 (22.34\%) respondents are not having the television sets and this is because of their financial crunches, some are not interested because their children may be studying in SSC, PUC and other courses., etc,.

The study also shows that all the TV holders are having the cable connection to watch their favorite channels.

\section{News Channels}

News channels had high impact on the society, these channels are very active in providing the latest news, political commentaries which mirrors on the society, latest happenings in the society, crime news etc. They also provide latest information on agricultural farming, new inventions, latest happenings in agricultural field, marketing of agricultural products, price index of the food grains and vegetables, etc.

Table 23: News Channels

\begin{tabular}{|l|l|l|l|l|}
\hline News Channels & No. of Channels & No. of Respondents & Percentage & CF \\
\hline Kannada & 08 & 187 & 62.33 & 62.33 \\
\hline Telugu & 09 & 70 & 23.33 & 85.66 \\
\hline Hindi & 03 & 20 & 06.67 & 92.34 \\
\hline English & 07 & 17 & 05.66 & 97.99 \\
\hline Others & 04 & 06 & 02.00 & 100 \\
\hline Total & $\mathbf{3 1}$ & $\mathbf{3 0 0}$ & $\mathbf{1 0 0 . 0 0}$ & \\
\hline
\end{tabular}

Table 23 shows that, there are large numbers of news channels available for watching in different languages. The spoken language of Chikkaballapur district people is Kannada but Telugu also is used by large number of people in this district due to the influence of the border state of Andhra Pradesh. Kannada has got 08 news channels and used by 187 (67.33\%) respondents and few of them are also using the other language news channels. This is followed by Telugu with 09 News channels and $70(23.33 \%)$ respondents are using these channels. Rural people in this district have no influence of other languages like English, Hindi, Tamil, Malayalam and others.

The hypotheses tested are Kannada and Telugu news channels are watching the Chikkaballapur district rural people and the hypotheses with one-sample test has been accepted and the null hypotheses has been rejected. The standard deviation is 1.076 and Chi-Square is $379.645^{\mathrm{a}}$ and the degree of freedom is 4 and the minimum expected cell frequency is 59.8 . 


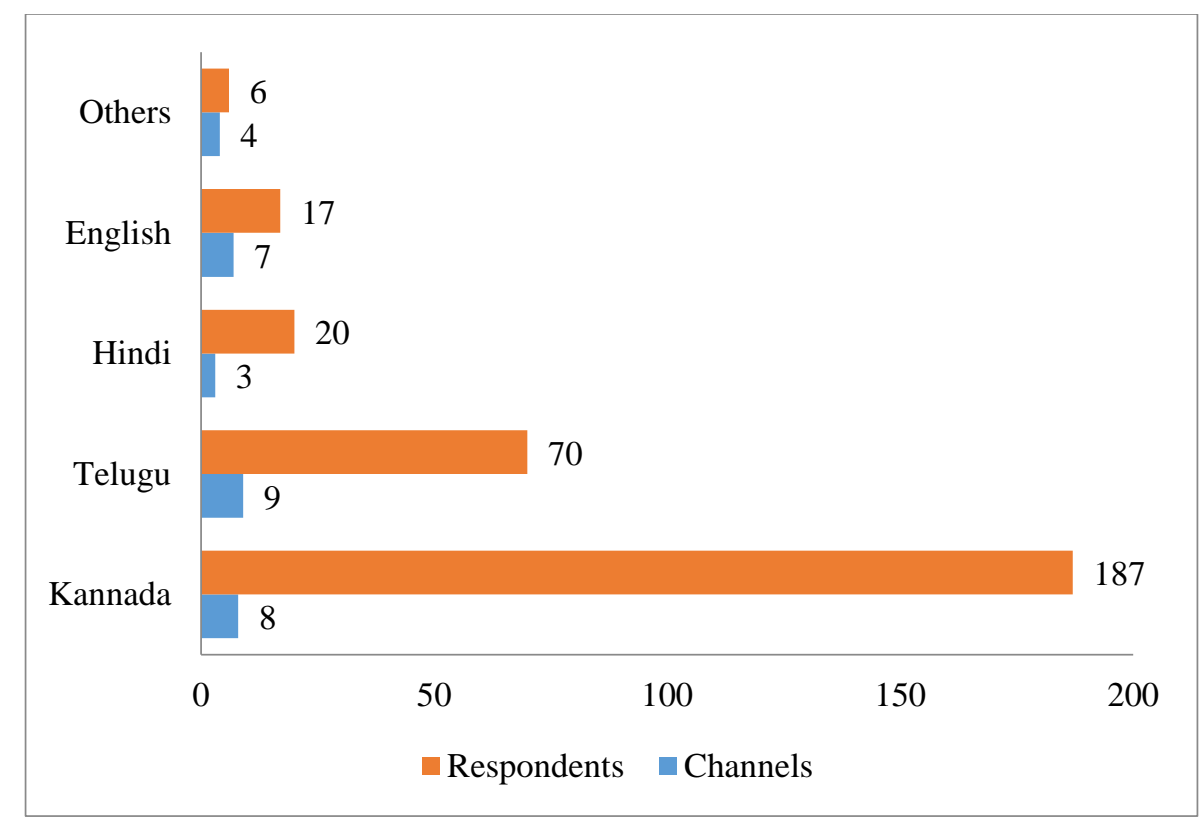

Graph 18: News Channels

Table 24: Watching of news channels

\begin{tabular}{|l|l|l|l|}
\hline & No. of Respondents & Percentage & CF \\
\hline Yes & 240 & 80.00 & 80.00 \\
\hline No & 60 & 20.00 & 100 \\
\hline Total & $\mathbf{3 0 0}$ & $\mathbf{1 0 0 . 0 0}$ & \\
\hline
\end{tabular}

For the question "Do you watch news channels?", 240 (80\%) respondents said that they watch news channels and it shows that they are interested in latest happenings of the taluk, state and country and $60(20 \%)$ respondents said that they are not interested in watching the news channels. Respondents are much interested in Kannada news channels and few of the respondents are also interested in watching the Telugu channels due to the influence of Telugu at border places. We asked to list the Kannada news channels that they watch. We have listed those channels below.

List of Kannada news channels watched

1) ETV Kannada

2) Udaya News

3) TV9

4) Kasturi News

5) Suvarna $24 X 7$ News

6) Public TV

7) Janashree News

8) DD News

Few of the respondents are not watching any kind of news channels because they are not interested in politics and they believe that all channels broadcast only politics. The most important point that we noted is that some of the respondents are not interested in watching the news channels and they are interested in watching serials and movies only. 


\section{Government Schools}

The Government schools are main pathfinders for the rural community to get the education for their children's for free. The Government of India has taken many initiatives to develop the schools and the government has provided good infrastructural facilities, teachers, library and mid-day meals to the children's up to the $10^{\text {th }}$ class. They taken the initiatives for education to all the children's under "Sarvashikshna Abayana" and they are have opened the residential schools for left outs like Kasturabha Residential School etc.

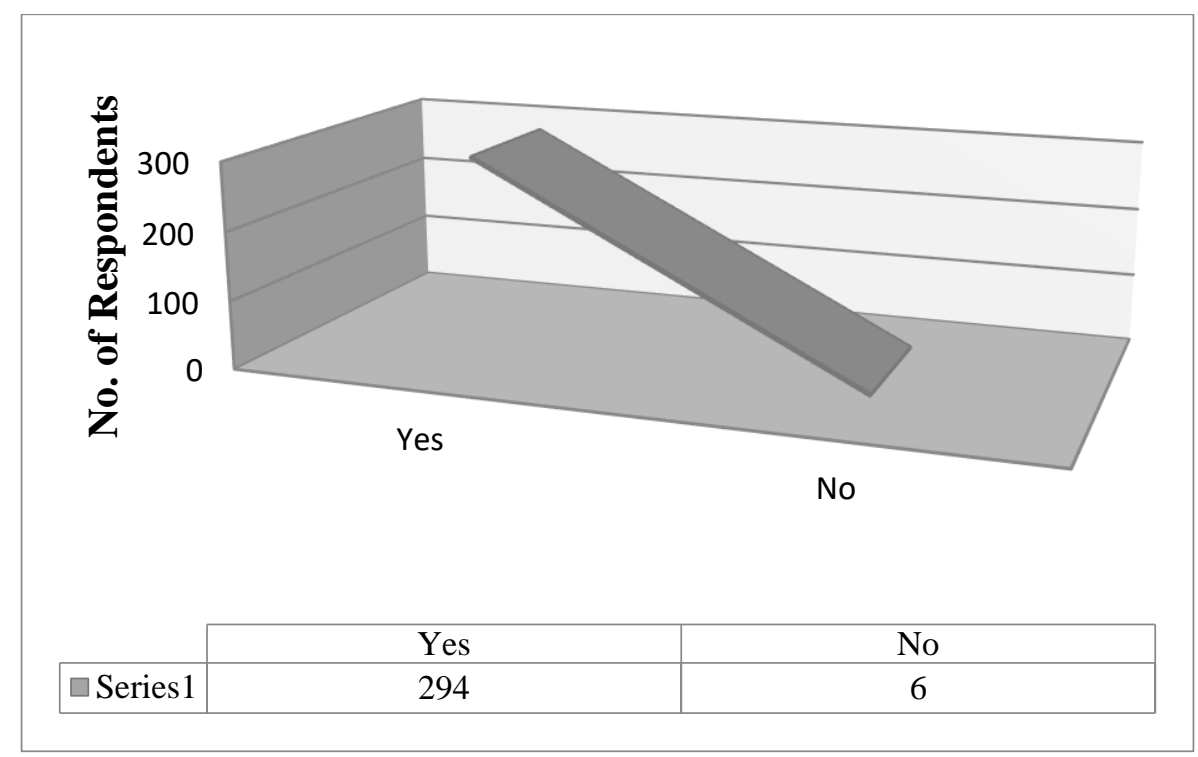

Graph 20: Government Schools

Graph 20 shows that, 294 (98\%) respondents stated that their villages are having government schools and $6(2 \%)$ respondents stated that their village do not have government schools in their villages due to strength of students being very low and village may be very thinly populated and schools may have been closed and tagged to the nearby schools.

The Government of Karnataka has initiated many programmes to develop the libraries in government schools. The government schools also have the library for the students of the school and the collections are based on the curriculum and popular children books on various subjects including fiction and non-fication.

\section{Findings}

1) $71.66 \%$ respondents of the study are farmers followed by $15 \%$ officials.

2) $60.66 \%$ males are the highest respondents and followed by $39.34 \%$ of female respondents.

3) $35 \%$ of the respondents are in the age group of $30-45$ followed by $28.34 \%$ in the age group of $15-30$.

4) $35 \%$ of respondents education is high school level and $30 \%$ of respondents are having primary schooling. $21.66 \%$ of respondents are not having any kind of education.

5) The $40 \%$ of the respondents are having up to Rs. 1,00,000 of annual income followed by $13.34 \%$ of respondents having Rs. 70,000 of annual income. 
6) The study reveals $50 \%$ of the rural community is facing the financial crunches to lead their dignified life in the present society. The rural community is striving to uplift their economy and they are facing many hurdles to achieve the better economy.

7) The study reveals that, central government and state government are initiated many schemes for construction of houses to the below poverty line people but even then $3 / 4$ $(17.34 \%)$ of the rural community are homeless.

8) $85.33 \%$ of the respondents are land holders and $14.67 \%$ of the respondents are not having any land.

9) $60 \%$ of the respondents are have cultivable land for agricultural purpose and $40 \%$ of the respondents are not having any cultivable land.

10) $37 \%$ of the respondents are having 5-10 acres of land followed by $26.66 \%$ of the respondents having 2-5 acres of land.

11) The study infers that more than $30 \%$ of the rural community is facing financial crunches to lead their life and other $20 \%$ of the rural community is managing their life.

12) $40 \%$ of respondents felt that television is the main source of information in rural areas followed by $30 \%$ respondents who said that Newspaper is the main source of information. $14.68 \%$ stated that library is the main source of income.

13) $80 \%$ of the respondents need information on areas like agricultural and non-agricultural sectors and $20 \%$ of the respondents are not in need of any information.

14) $80 \%$ of the respondents stated that media has more impact and $20 \%$ of the respondents felt that media has no impact on them.

15) $70 \%$ of the respondents said that media is more useful than library and $30 \%$ of the respondents said that library is more useful than media.

16) $30 \%$ of the respondents are getting their required information from grampanchyat offices followed by $26.67 \%$ of the respondents getting their information from agricultural offices.

17) The table 21 infers that $1 / 2$ of the respondents are getting their required information from their friends, farmers and from literates of their villages.

18) $77.66 \%$ of the respondents are having television in their homes and $22.34 \%$ of respondents are not having television in their homes.

19) $67.33 \%$ of the respondents use Kannada channels for getting useful information and $23.33 \%$ of the respondents use Telugu channels for some purposes.

20) $80 \%$ of the respondents are use the News channels and $20 \%$ of them do not use the News channels.

21) $98 \%$ of the villages are having the government schools and $2 \%$ of the villages do not have government schools.

\section{Conclusion}

Library is a social institution. Therefore, changes in the society will affect the role of a Librarian. The present-day society is undergoing fast changes. These have made an impact on libraries and as such there are various implications on libraries. For the proper growth and development of libraries, it is essential that librarians should be able to understand and appreciate the changes in social, economic, political, technological and ethical environment. They should rather take advantage of the same. Above all they must respond to the changing conditions. 
The best solution to overcome the lack of resources is to set up a national network of libraries. The network should include various types of libraries like national libraries, public libraries, academic libraries, special libraries, government libraries and school libraries. National Library in Kolkata should be at the apex. Small library authorities may be replaced by large authorities. Resource sharing must be implemented seriously. Management of resources should be improved to achieve efficiency and effectiveness.

The present study emphasis the need for the gram panchayat libraries. Libraries are disseminating the information to the rural people to uplift their economy. The rural libraries are playing vital role in dissemination of information to the rural people. The study makes one to understand the socioeconomic background of rural community, impact of media on the productive sectors like agriculture and non-agricultural activities, to assess the difficulties and problems of rural people in getting the information and to analyze the impact of dissemination of information to the rural community.

\section{References}

[1] Asaba, J. F., \& all, e. (2006). Bridging the Information and Knowledge Gap between Urban and Rural Communities through Rural Knowledge Centres: Case Studies from Kenya and Uganda. Quarterly Bulletin of the International Association of Agricultural Information Specialists , 143151.

[2] Kaula, P. N. (2006). Need And Development of Libraries In Rural India. Herald of Library Science, 52-59.

[3] Shivalingappa, A., \& Tadasad, P. G. (2009). Status of Rural Librarianship - Gram Panchayat Library System in Hyderabad Karnataka Region. SRELS Journal of Information Management , 189-194. 